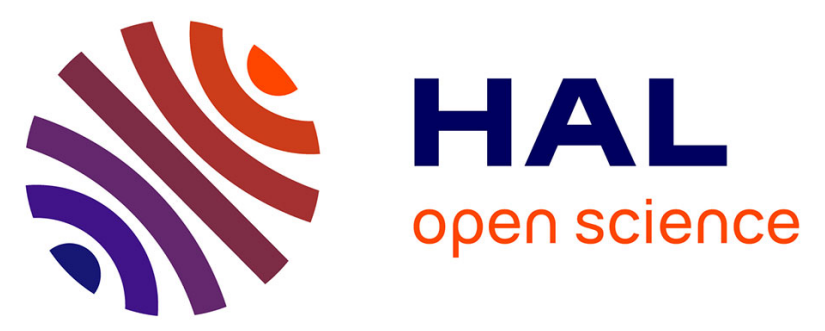

\title{
Comment on "Ccl2, Cx3cr1 and Ccl2/Cx3cr1 chemokine deficiencies are not sufficient to cause age-related retinal degeneration" by Luhmann et al. (Exp. Eye Res. 2013; 107: 80.doi: 10.1016).
}

Christophe Combadière, William Raoul, Xavier Guillonneau, Florian Sennlaub

\section{To cite this version:}

Christophe Combadière, William Raoul, Xavier Guillonneau, Florian Sennlaub. Comment on "Ccl2, $\mathrm{Cx} 3 \mathrm{cr} 1$ and $\mathrm{Ccl} 2 / \mathrm{Cx} 3 \mathrm{cr} 1$ chemokine deficiencies are not sufficient to cause age-related retinal degeneration" by Luhmann et al. (Exp. Eye Res. 2013; 107: 80.doi: 10.1016).. Experimental Eye Research, 2013, 111, pp.134-5. 10.1016/j.exer.2013.02.002 . inserm-00990798

\section{HAL Id: inserm-00990798 https://www.hal.inserm.fr/inserm-00990798}

Submitted on 14 May 2014

HAL is a multi-disciplinary open access archive for the deposit and dissemination of scientific research documents, whether they are published or not. The documents may come from teaching and research institutions in France or abroad, or from public or private research centers.
L'archive ouverte pluridisciplinaire $\mathbf{H A L}$, est destinée au dépôt et à la diffusion de documents scientifiques de niveau recherche, publiés ou non, émanant des établissements d'enseignement et de recherche français ou étrangers, des laboratoires publics ou privés. 


\section{Accepted Manuscript}

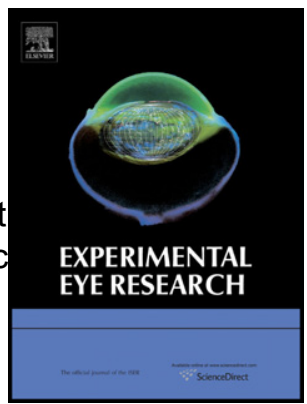

Comment on " $\mathrm{Ccl} 2, \mathrm{C} \times 3 \mathrm{cr} 1$ and $\mathrm{Cc} 2 / \mathrm{C} \times 3 \mathrm{cr} 1$ chemokine deficiencies are not sufficient to cause age- related retinal degeneration" by Luhmann et al.(Exp Eye Res. 2012 Dec 8. doi:pii: S0014-4835(12)00342-9.)

Christophe Combadière, William Raoul, Xavier Guillonneau, Florian Sennlaub

PII: S0014-4835(13)00030-4

DOI: $\quad$ 10.1016/j.exer.2013.02.002

Reference: YEXER 6103

To appear in: Experimental Eye Research

Received Date: 2 January 2013

Revised Date: 29 January 2013

Accepted Date: 2 February 2013

Please cite this article as: Combadière, C., Raoul, W., Guillonneau, X., Sennlaub, F., Comment on " $\mathrm{Cc} 12, \mathrm{Cx} 3 \mathrm{cr} 1$ and $\mathrm{Ccl} 2 / \mathrm{Cx} 3 \mathrm{cr} 1$ chemokine deficiencies are not sufficient to cause age- related retinal degeneration" by Luhmann et al.(Exp Eye Res. 2012 Dec 8. doi:pii: S0014-4835(12)00342-9.), Experimental Eye Research (2013), doi: 10.1016/j.exer.2013.02.002.

This is a PDF file of an unedited manuscript that has been accepted for publication. As a service to our customers we are providing this early version of the manuscript. The manuscript will undergo copyediting, typesetting, and review of the resulting proof before it is published in its final form. Please note that during the production process errors may be discovered which could affect the content, and all legal disclaimers that apply to the journal pertain. 


\title{
Comment on " $\mathrm{Ccl} 2, \mathrm{Cx} 3 \mathrm{cr} 1$ and $\mathrm{Ccl} / \mathrm{Cx} 3 \mathrm{cr} 1$ chemokine deficiencies are not sufficient to cause age- related retinal degeneration" by Luhmann et al.(Exp Eye Res. 2012 Dec 8. doi:pii: S0014-4835(12)00342-9.)
}

\author{
Christophe Combadière, William Raoul, Xavier Guillonneau, Florian Sennlaub
}

We are writing to you concerning a recent publication in this journal by Luhmann et al. (Exp Eye Res. 2013;107:80). In this manuscript the authors describe the absence of age-related subretinal macrophage/microglial cells $(\mathrm{M} \phi / \mathrm{MC})$ and retinal degeneration in notably the $\mathrm{Cx} 3 \mathrm{cr}^{-/-}$mice. The authors suggest that their study contradicts Chinnery et al. (Neurobiol Aging. 2012; 33(8):1769) and our previous reports of age- and light-induced (Combadiere et al., J Clin Invest. 2007;117(10):2920 ; Raoul et al., J Neuroimmunol. 2008;198(1-2):56) subretinal M $\phi / M C$ accumulation and associated photoreceptor degeneration. This phenotype was described in both, pigmented $\mathrm{C} 57 \mathrm{BL} / 6$ and BALB albino background, in $\mathrm{Cx} 3 \mathrm{crl}^{-/-}$knockout and $\mathrm{Cx} 3 \mathrm{cr} 1^{\mathrm{GFP} / \mathrm{GFP}}$ knockin mice (see references cited above).

The title of the manuscript could suggest to the reader that our results are not reproducible and the authors state that their "findings are in clear contrast to several reports that describe an agerelated retinal degeneration in other chemokine knockout mouse lines", including the $\mathrm{Cx} 3 \mathrm{cr}^{-/-}$ mice. We would like to explain why we think that such conclusions cannot be drawn from the presented data.

A contamination with the $r d 8$ mutation of the $\mathrm{Crb} 1$ gene has recently been recognized to cause early onset, severe retinal degeneration in $\mathrm{Ccl}^{-/-} \mathrm{Cx} 3 \mathrm{cr}^{-/-}$mice, as described in several publications, independently of their $\mathrm{Ccl} 2$ and $\mathrm{Cx} 3 \mathrm{cr} 1$ deletions. Luhman et al. question "whether the previously reported phenotypes of different chemokine single knockout mice might also have been affected by the $\mathrm{rd} 8$ mutation". As communicated to the authors, the $\mathrm{Cx} 3 \mathrm{cr}^{-1-}$ mice and $\mathrm{Cx} 3 \mathrm{cr} 1^{\mathrm{GFP} / \mathrm{GFP}}$ mice used in our experiments are not contaminated by the $r d 8$ mutation.

We have previously reported that ambient light conditions are crucial for the Cx 3 cr1-dependent increase in subretinal $\mathrm{M} \phi / \mathrm{MC}$ accumulation, as raising $\mathrm{Cx} 3 \mathrm{cr} 1^{-/}$BALB mice in the dark prevented (Combadiere et al. 2007, cited above), and a bright-light-challenge that does not induce subretinal inflammation in C57BL6/J mice, induced the phenotype in $\mathrm{Cx} 3 \mathrm{cr} 1^{\mathrm{GFP} / \mathrm{GFP}}$ C57BL6/J mice (Raoul et al. 2008, cited above). We observed the age-dependent presence of $\mathrm{M} \phi / \mathrm{MC}$ in $\mathrm{Cx} 3 \mathrm{cr}^{-/-}$and $\mathrm{Cx} 3 \mathrm{cr} 1^{\mathrm{GFP} / \mathrm{GFP}} \mathrm{C} 57 \mathrm{BL} 6 / \mathrm{J}$ mice that were raised under 12-h light/12-h dark cycles (100-500 lux at the cage level, with no additional cover in the cage; Combadiere $e t$ al. 2007, cited above). Since our publication in 2007, we have observed this phenotype in over 30 Cx3cr1-deficient C57BL6/J mice with age (12 months and older; raised in the indicated light conditions) and in over 40 light-exposed Cx3cr1-deficient C57BL6/J mice, compared to a similar amount of wildtype controls. Chinnery et al. reproduced the increased subretinal $\mathrm{M} \phi / \mathrm{MC}$ accumulation in $\mathrm{Cx} 3 \mathrm{cr} 1^{\mathrm{GFP} / \mathrm{GFP}} \mathrm{C} 57 \mathrm{BL} 6 / \mathrm{J}$ and $\mathrm{Cx} 3 \mathrm{cr} 1^{\mathrm{GFP} / \mathrm{GFP}}$ BALB mice (also $r d 8$-free, personal 
communication) at 230-275 lux in young adults. Under their conditions the accumulation further increased with age and was not statistically different anymore in $\mathrm{Cx} 3 \mathrm{cr} 1^{\mathrm{GFP} /+} \mathrm{Cx} 3 \mathrm{cr} 1^{\mathrm{GFP} / \mathrm{GFP}}$ at a massive $180 \mathrm{M} \phi / \mathrm{MCs} / \mathrm{mm}^{2}$ in 20-month-old BALB mice, suggesting that a maximal $\mathrm{M} \phi / \mathrm{MC}$ cell accumulation can be reached in the subretinal space.

$\mathrm{Ng}$ and Streilein (Invest Ophthalmol Vis Sci. 2001;42(13):3301) showed that subretinal M $\phi / \mathrm{MC}$ accumulate in albino mice and subretinal $\mathrm{M} \phi / \mathrm{MCs}$ are cleared when transferred from light to dark conditions. In $\mathrm{Cx} 3 \mathrm{cr}^{-/-}$mouse brains, macrophages clear less efficiently from the injection site compared to wildtype macrophages (Cardona et al., Nat Neurosci. 2006;9(7):917). In preliminary studies (Levy et al., ARVO 2011), we have shown that $\mathrm{Cx} 3 \mathrm{cr}^{-/-}$macrophages present a similar impaired clearance from the subretinal space, which could explain the subretinal $\mathrm{M} \phi / \mathrm{MC}$ accumulation in $\mathrm{Cx} 3 \mathrm{cr} 1$-deficient animals we described.

The mice used in the studies described by Luhmann et al. were raised under a 12h/12h dark-light cycle with a mean luminescence during the light period at the bottom of the cage of $33 \pm 281 \mathrm{x}$. Furthermore, the animals had access to protection from light exposure (e.g., paper roll and excess of bedding) inside the cage, which allowed them to burrow. The light-conditions used in the described experiments were, therefore, significantly dimmer than the light conditions used in the previous publications.

We never suggested that $\mathrm{Cx} 3 \mathrm{cr}^{-/-}$or $\mathrm{Cx} 3 \mathrm{cr} 1^{\mathrm{GFP} / \mathrm{GFP}} \mathrm{C} 57 \mathrm{BL} 6 / \mathrm{J}$ mice raised under such dim-light conditions accumulate subretinal $\mathrm{M} \phi / \mathrm{MCs}$ or display age-related photoreceptor degeneration. In fact we have emphasized in all our related publications that light conditions are crucial for obtaining the phenotype.

Therefore, we believe that the only conclusion that can be drawn safely from the presented data is that none of the mouse strains used develop subretinal $\mathrm{M} \phi / \mathrm{MC}$ accumulation or retinal degeneration under very dim light conditions. The comparison of theresults described by Luhmann et al. to those obtained in our studies and their interpretation as a "clear contrast" to our published findings (which suggests our results were not reproducible in their laboratory) are not justified, as the conditions used in the two studies were not comparable. 